respeto por la vida privada vs. respeto total por la vida privada). Las 36 historias fueron obtenidas por el cruce ortogonal de los 4 factores: $3 \times 3 \times 2 \times 2=36$. Los resultados de la muestra francesa fueron comparados con resultados previos de una muestra venezolana (Guédez \& Mulllet, 2014). Los resultados no mostraron diferencias en la importancia dada a la protección social entre los participantes franceses y venezolanos. Además, la interacción crucial de cuatro formas fue significativa en un nivel muy riguroso, mientras que la interacción de cinco formas, incluyendo país, no lo fue. Entonces, se puede considerar con seguridad que la manera en que los derechos humanos son conceptualizados es correctamente expresada por la ecuación: Respeto por los derechos humanos juzgado $=$ Privacidad $\mathrm{x}$ Libertades civiles $\mathrm{x}$ Equidad x Protección Social.

Palabras clave

derechos humanos; Francia; indivisibilidad; universalidad.

\section{French and Venezuelan People's Conceptualization of Human Rights: Indivisibility and Universality Issues}

The Universal Declaration of Human Rights (UDHR) was adopted by the international community on December 1948. At the time, the Chair of the Commission on Human Rights, Eleanor Roosevelt, stated that the Declaration "is not and does not purport to be a statement of law or legal obligation," but it means "to serve as a common standard of achievement for all nations" (United Nations General Assembly, 1948).

By stating that the UDHR was a common standard of achievement for all nations, the United Nations (UN) clearly posited that it was universally valid, irrespective of local customs and traditions (Cerna, 1994). In the second UN World Conference on Human Rights, which took place in Vienna in 1993, the UN expressed concern with dissident views regarding the universality of HR. The conference rejected the idea that HR can be conceptualized differently from one country to another; that is, as a function of historical traditions and religious beliefs.

\section{How do People Conceptualize HR?}

The way people in the US conceptualize HR has been examined by Diaz-Veizades, Widaman,
Little, and Gibbs (1995). They created a 116item Human Rights Questionnaire based on the 30 articles of the UDHR, and, by using factor analysis, examined the level of endorsement to these items expressed by US College students. They found four separable factors: Social security (e.g., "Everyone has the right to an adequate standard of living"), Civilian constraint (e.g., "Detention of individuals for political reasons is wrong"), Equality (e.g., "Women and men should have equal rights in divorce"), and Privacy (e.g., "A person's home is his castle and should not be interfered with by others"). In addition, participants tended to strongly endorse the Social Security, Equality and Privacy items $(M>6$ out of 7), but were ambivalent regarding the Civilian constraint items $(M=4)$.

Similar studies, conducted on other US samples (Crowson, 2004) and in Cameroon (Pirttilä-Backman, Kassea, \& Sakki, 2009) supported, with some variations, the four-factor model. Other studies have shown that support to HR depended on authoritarian attitudes (Swami et al., 2012), and on civic education (Stellmacher $\&$ Sommer, 2008).

Building on these works, Guédez and Mullet (2014) examined an aspect of Human Rights that has been left practically untouched in previous studies: the indivisibility of human rights. According to UNDHR, HR are indivisible; that is, they cannot successfully exist but in combination with one another: "The ideal of free human beings enjoying civil and political freedom and freedom from fear and want can only be achieved if conditions are created whereby everyone may enjoy his civil and political rights, as well as his social, economic and cultural rights" (Preamble of the International Covenant on Civil and Political Rights and the International Covenant on Economic Social and Cultural Rights, 1966). Guédez and Mullet (2014) worked on a Venezuelan sample of adults; their research question was: Do people perceive Human Rights as a simple collection of more or less independent rights or as a bundle of interdependent and related rights?

If people perceive $\mathrm{HR}$ as a collection of independent rights, then the model of perception 
could be written as follows: Judged Respect for $\mathrm{HR}=$ Privacy + Civil Liberties + Equality + Social Protection. In this equation the "+" signs express the independence of the four factors. In the judgment process, they simply add their effects. Alternatively, if people perceive $\mathrm{HR}$ as a bundle of interdependent and related rights, then the model of perception could be written: Judged Respect for HR = Privacy $x$ Civil Liberties $\mathrm{x}$ Equality $\mathrm{x}$ Social Protection. In this equation the " $x$ " signs express the interdependence of the four factors. In this case, a high level of judged respect for HR can be only observed if all factors have a high level.

Guédez and Mullet (2014) presented their participants with short reports about fictitious countries. These reports included four kinds of information: a) the level to which citizens in the country were offered social protection; b) the level of respect for Civil Liberties in the country; c) whether equality between citizens in the country was the norm;and d) whether citizen's private life was respected. Participants were asked to judge the extent to which Human Rights were, from their personal perspective, respected in each case.

Guédez and Mullet (2014) found support for the view that Venezuelan people perceive Human Rights as a bundle of interdependent and related rights; that is, they found support for the indivisibility model of HR perception. There were, however, two limitations to this view. Firstly, the impact of the Social Protection factor was clearly weaker than the impact of the other factors. It accounted for about 10\% of the explained variance whereas the other factor accounted for each about 30\%. Secondly, the three-way and four-way interactions involving this factor were not always significant at the chosen $p=0.001$ level. There was thus the possibility that the model of perception of HR among Venezuelan people is a mixed, additivemultiplicative model: Judged Respect for $\mathrm{HR}=$ (Privacy x Civil Liberties x Equality) + Social Protection.

\section{The Present Study}

The present study addressed two concerns. The first one was: Is the weak impact of the Social Protection factor Venezuela-specific? Guédez and Mullet (2014) argued that the seemingly lower impact of social protection as compared with other basic rights may be explained by the fact that some rights are easier to "implement" than others. Even in poor nations, a) equality can be instituted by law, even if not easily realized, and b) the government and its police can respect privacy, at least to some extent. In contrast, building a system of social protection supposes adequate funding that some states such as Venezuela, cannot always fully afford. There is, however, an alternative, more direct explanation: Social protection is considered as less important than other rights by people in general and not just by Venezuelans. The second one was: Is the non-significance of the three- and four-way interactions involving this factor simply due to lack of statistical power?

To answer both concerns, we turned to a sample of participants from France. France is a richer country than Venezuela; it has, a long time ago, a system of social protection that is costly but efficient (Sorum, 2005). If the importance given to this factor depends on the wealth of the participants' country, then its impact would be stronger in the French sample than in the Venezuelan sample. Also, France has a long tradition of concern for HR. La Déclaration des Droits de l'Homme et $d u$ Citoyen was a crucial document issued in 1789, at the outset of first French Revolution. More recently, René Cassin, a French jurist, played an important role in the creation of the UDHR adopted by the United Nations General Assembly in 1948 (Glendon, 2004). Therefore, it may be assumed that, for historical reasons, French people are sensitized to the issue of HR. If the structure of ratings observed in the Venezuelan and the French samples are, in the present study, similar, and if the interdependence model hold de facto for both samples, then, the lack of significance of some interactions reported in the study by Guédez 
and Mullet (2014) could, as suggested by the authors, be attributed to the lack of statistical power. If, in the present study, both sets of ratings significantly differ, then the assumption that HR are conceptualized in an interdependent way everywhere would no longer be tenable (Dahre, 2017).

In summary, if the importance attributed to each kind of rights varied as a function of the level of development of a country, and if the level of interdependence of these rights varied as a function of some other factor(s), then the universality of HR would be severely questioned, at least regarding the way people from different countries conceptualize them.

\section{Method}

\section{Participants}

Fifty unpaid French participants (26 females and 24 males) participated in the present study. Their mean age was 33 years $(S D=12.72$, range $=18-63)$. Twenty two participants $(44 \%)$ had a high school degree, 20 (40\%) had a higher education diploma, and eight (16\%) had a graduate degree. Thirty (60\%) participants were single, 12 (24\%) were cohabitating, 7 (14\%) were married, and 1 (2\%) was divorced. Nine participants (18\%) declared themselves as believers in God and 41 (82\%) declared themselves as non-believers in God. All participants lived in the area of Toulouse, in the Southwest of France. Data were gathered in 2016 using snowball sampling, whereby the author personally knows the first round of participants (from her circle of friends or acquaintances), who after participating help her to find more people to participate, and so on.

\section{Material}

The material was the same as the one used in Guédez and Mullet (2014) study. It consisted of 36 cards showing a story of a few lines depicting the current situation as regards Human Rights in a particular country. Four critical items of information were provided: a) the degree in which the State offers Social Protection to the citizens (not at all, intermediate or complete);b) the level of respect for Civil Liberties in the country (no respect, intermediate, full respect);c) the level of Equality between citizens (inequality of rights vs. equality of right);and d) the level of respect for the Private Life of the citizens (no respect for private life vs. full respect for private life). The 36 stories were obtained through the orthogonal crossing of the four factors: $3 \times 3 \times 2$ $\mathrm{x} 2=36$.

A sample story is the following: "The republic of Biranie guarantees the social protection of the citizens. The State ensures that all citizens have enough incomes to enjoy a decent way of life and the means to maintain themselves in good health. Working conditions are protected. People with handicaps receive adequate support. Civil Liberties are guaranteed. All the people have the right to freely express their opinions in any circumstance. The media are free. The citizens cannot be arrested without a good reason, and those arrested are entitled to legal aid. Equality between citizens is formally guaranteed. Men and women have the same rights. Social minorities are not a target of any particular discrimination. Religion liberty is guaranteed. All citizens, according to their means, are entitled to own a property. In business the rule is to pay all workers in an equally way. Finally, private life is fully respected. There is not wiretapping. The mail is not spied. A person's home cannot be violated without a good reason. Nobody has the right to intrude on people's sexual life. To what extent do you think that, in this country, human rights are respected?"

The response scale was an 11 point scale with "Not at all" at the left extreme and "Completely" at the right extreme. Each country was attributed a different (fictitious) name.

\section{Procedure}

Each participant was tested individually in a calm environment (his/her own house, a 
friend's house, or at their lunch break at work). The procedure followed Anderson's recommendations for this kind of study (Anderson, 2008, 2016, 2018; see also Mullet et al., 2016). They took 35 to 50 minutes to complete the whole task.

\section{Results}

The mean and standard deviation for each vignette are shown in Appendix A. An ANOVA was conducted on the raw data from the French sample and on the data taken from the study by Guédez and Mullet (2014). The ANOVA design was, therefore, Country x Respect for Private Life $\mathrm{x}$ Equality $\mathrm{x}$ Civil Liberties $\mathrm{x}$ Social Protection, 2 $x 2 \times 2 \times 3 \times 3$. The results are shown in Appendix B.

The four main effects were significant. Respect for Human Rights was considered higher a) when Private Life was respected in the country $(M$ $=4.05)$ than when it was not $(M=1.94)$, b) when Equality of rights between citizens was instituted $(M=4.15)$ than when it was not $(M=1.84)$. Also, the overall level of respect for Human Rights was considered higher when Civil Liberties were present $(M=4.43)$ than when they were absent $(M=1.98)$. Post-hoc analyses using the Tukey honestly significant difference test showed that the mean value observed when Civil Liberties were not fully present $(M=2.57)$ differed significantly from both other means, $p<0.001$. Finally, the overall level of respect for Human Rights was considered higher when Social Protection of the population was instituted $(M=3.71)$ than when it was not $(M=2.29)$. Post-hoc analyses showed that the mean value observed when Social Protection was intermediate $(M=2.99)$ differed significantly from both other means, $p<0.001$.

\section{Figure 1}

Patterns of results observed on the whole sample. In each panel, a) the mean respect for Human Rights judgments are on the $y$-axis, $b$ ) the three levels of respect for Civil Liberties are on the $x$-axis, and c) the three curves correspond to the three levels of social protection. Each panel corresponds to a combination of Equality and Respect for Private life
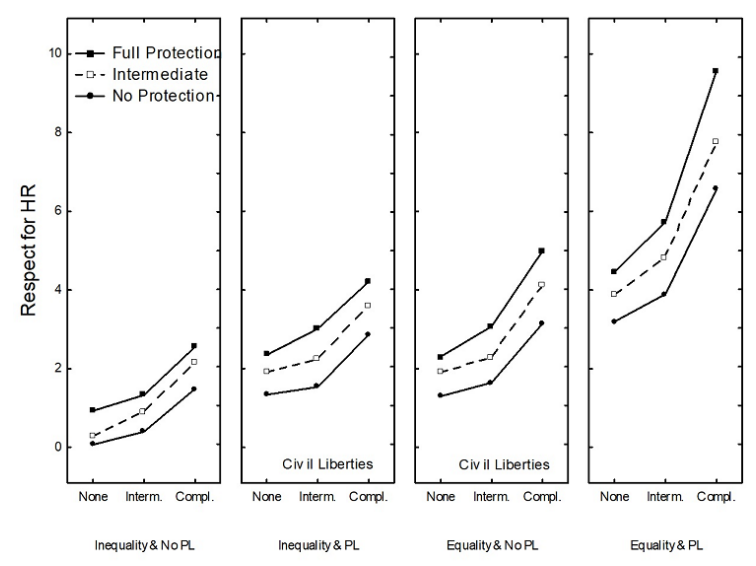

No two-way interaction involving Country was significant at the chosen threshold. The only interaction that was significant at the 0.005 threshold was Country x Equality. The impact of equality was slightly stronger in the French $(4.17-1.66=2.51)$ than in the Venezuelan sample $(4.12-2.02=2.1)$. All other two-way interactions were significant, and their bilinear component was also significant whereas other components were not.

No three-way interaction involving Country was significant at the chosen threshold, except Country x Civil Liberties x Social Protection. The Civil Liberties $\mathrm{x}$ Social Protection interaction was stronger in the Venezuelan than in the French sample. In both samples, the effect of social protection was higher when civil liberties were present than when it was absent, but the difference of effects was higher in the Venezuelan sample $(5.56-3.58=1.98$ as compared with $2.59-1.43=1.16)$ than in the French sample $(5.1-3.55=1.55$ as compared with $2.43-$ $1.43=1)$. The difference of differences was 0.82 in the Venezuelan sample and 0.55 in the French sample. All other three-way interactions were significant, except for Respect for Private 
Life $\mathrm{x}$ Equality $\mathrm{x}$ Social Protection that was only significant at the 0.02 level although its trilinear component was significant at the 0.01 level. Also, the trilinear component of Respect for Private Life x Civil Liberty x Social Protection was significant at the 0.005 threshold only. The other components of all these interactions were never significant.

No four-way interaction involving Country was significant at the chosen threshold. The Respect for Private Life $\mathrm{x}$ Equality $\mathrm{x}$ Civil Liberties x Social Protection interaction, and its quadri-linear component, were significant. This interaction is shown in Figure 1. In the two right-hand panels, curves are gradually more ascending, more separated, and more diverging on the right than in the two left hand panels. Finally, the five-way interaction was not significant. The ratings given by French and Venezuelan participants formed a similar pattern. The linear correlation computed over both sets of means was 0.98 .

\section{Discussion}

As stated earlier, the present study addressed two concerns. The first one was: "Is the weak impact of the Social Protection factor Venezuelaspecific?" The response is unambiguously: "No". There was no difference in the importance given to Social Protection between French and Venezuelan participants. It must therefore be considered that although Social Protection was considered as part of HR among all participants, the importance given to this factor was not viewed as crucial, at least compared to the one attributed to respect for Private Life, Equality among citizens, and Civil Liberties. As early as 1948, the Chair of the Commission on Human Rights .- Eleanor Roosevelt .- stated that the Declaration should not try to stipulate the methods for guaranteeing the realization of those rights. Methods of implementation "would necessarily vary from one country to another and such variations should be considered not only inevitable but salutary" (Glendon, 2004, p. 7). The implementation of social protection heavily depends on the level of economic development. It is interesting to observe that participants were seemingly aware of it: Even the French participants did not insist too much on the importance to be given to this factor.

The second concern was: "Is the nonsignificance of the three- and four-way interactions involving the Social Protection factor simply due to lack of statistical power?" The response was: "Probably yes." In the present study, the crucial four-way interaction was significant at a very stringent level, and the five-way interaction involving Country was not. Even if some lower level interactions were not significant at this level, they were significant at the conventional 0.05 level, and their multilinear components were always significant at the 0.01 level. It can thus be safely considered that the way HR are conceptualized is correctly expressed by the equation: Judged Respect for HR $=$ Privacy $x$ Civil Liberties $\times$ Equality $x$ Social Protection.

From French people's viewpoint as well as from Venezuelan people's viewpoint: (a) enjoying one basic right (e.g., enjoying free press) is better than enjoying no right at all, and that enjoying two basic rights is better than enjoying just one, and so on; (b) enjoying any right at an intermediate level (e.g., enjoying some level of a Civil Liberty) is not very different than not enjoying this right, although it is better than not enjoying this right at all, and, as already stated before; c) only the complete enjoyment of all basic rights can be considered as enjoyment of Human Rights. These findings support the view that $\mathrm{HR}$ are conceived in a way that is possibly universal (Dahre, 2017). It is, of course, too early to firmly state such a view but the similarity between mean ratings (see Table 1) observed in two different nations: a) France, a predominantly atheist country, with a long tradition of democracy, with a quite stable political life, and with a level of development that is comparable to that of the United Kingdom; and b) Venezuela, a predominantly religious country, where democracy has frequently been endangered, with a chaotic political life (Amnesty International, 2016), and with a 
level of development that has recently tended to decrease rather than increase (Dreier \& Goodman, 2017).

Future studies, using samples of participants from other parts of the world (e.g., Sub-Saharan Africa, India or China) should examine further the issue of universality of perception of HR. Do people from "collectivistic" countries differ from people from "individualistic" countries regarding the weight they give to privacy or to equality or regarding the perceived level of rights' interdependence? Future studies should also examine, using additional measurements, the effect on people's judgments of various classical variables in political psychology (e.g., left-wing and right-wing authoritarianism, Cohrs, Maes, Kielmann, \& Moschner, 2007), or in cultural psychology (e.g., survivalism versus selfexpression, Inglehart \& Norris, 2003).

\section{References}

Amnesty International. (2016). Venezuela: Las violaciones de derechos humanos cometidas por fuerzas de seguridad deben investigarse. Retrieved from https://www.es.amnesty.org /en-que-estamos/noticias/noticia/articulo/v enezuela-las-violaciones-de-derechos-hum anos-cometidas-por-fuerzas-de-seguridad-d eben-ser-investig/

Anderson, N. H. (2008). Unified social cognition. New York, NY: Psychology Press.

Anderson, N. H. (2016). Information integration theory: Unified psychology based on three mathematıcal laws. Universitas Psychologica, 15(3). https://doi.org/10.11144/Javeriana.u psy15-3.iitu

Anderson, N. H. (2018). Moral science. New York, NY: Psychology Press.

Cerna, C. M. (1994). Universality of human rights and cultural diversity: Implementation of human rights in different socio-cultural contexts. Human Rights Quarterly, 16(4), 740-752.

Cohrs, J. C., Maes, J., Kielmann, S., \& Moschner, B. (2007). Determinants of human rights attitudes and behavior: A comparison and integration of psychological perspectives. Political Psychology, 28(4), 441-469.

Crowson, H. M. (2004). Human Rights attitudes: Dimensionality and psychological Correlates. Ethics $\mathcal{B}$ Behavior, 14(3), 235-253.

Dahre, U. J. (2017). Searching for a middle ground: anthropologists and the debate on the universalism and the cultural relativism of human rights. The International Journal of Human Rights, 21 (5), 611-628. https://doi.o $\mathrm{rg} / 10.1080 / 13642987.2017 .1290930$

Diaz-Veizades, J., Widaman, K. F., Little, T. D., \& Gibbs, K. W. (1995). The measurement and structure of human rights attitudes. The Journal of Social Psychology, 135(3), 313-328.

Dreier, H., \& Goodman, J. (2017). Venezuela military trafficking food a country goes hungry. News 1130 . Retrieved from http://www.news1130.com/2017/01/0 1/venezuela-military-trafficking-food-as-co untry-goes-hungry-2/

Glendon, M. A. (2004). The rule of law in the Universal Declaration of Human Rights. Northwestern Journal of International Human Rights, 2(1), 1-19.

Guédez, A. G., \& Mullet, E. (2014). Venezuelan adult's views on the indivisibility of human rights: A preliminary study. Psicológica: International Journal of Methodology and Experimental Psychology, 35, 621-633.

Inglehart, R., \& Norris, P. (2003). Rising tide: Gender equality and cultural change around the world. Cambridge, England: Cambridge University Press.

Mullet, E., López López, W., Kpanake, L., Mukashema, I., Armange, R., Kamble, S., ... Neto, F. (2016). Functional measurement in the field of ethics in politics. Universitas Psychologica, 15(3). https://doi.org/10.11144/Javeriana.u psy15-3.fmf

Pirttilä-Backman, A. -M., Kassea, R., \& Sakki, I. (2009). Human and peoples' rights: Social representations among Cameroonian students. International Journal of Psychology, 44(6), 459-467. 
Sorum, P. C. (2005). France tries to save its ailing National Health Insurance System. Journal of Public Health Policy, 26(2), 231-245.

Stellmacher, J., \& Sommer, G. (2008). Human rights education, an evaluation of university seminars. Social Psychology. Special Issue: Social Psychology and Peace, 39(1), 70-80.

Swami, V., Nader, I. W., Pietschnig, P., Stieger, S., Tran, U. S., \& Voracek, M. (2012). Personality and individual difference correlates of attitudes toward human rights and civil liberties. Personality and Individual Differences, 53(4), 443-447.

United Nations General Assembly. (1948). General Assembly resolution 217A. Report. Paris, France: United Nations the Universal Declaration of Human Rights.

\section{Appendix A}

\section{Means and Standard Deviations Observed for Each Vignette. F = France,}

\section{$\mathrm{V}$ = Venezuela (data from the 2014 study)}

\begin{tabular}{|c|c|c|c|c|c|c|}
\hline \multicolumn{4}{|c|}{ Factors } & \multirow{2}{*}{$-M(F)$} & \multirow{2}{*}{$S D(F)$} & \multirow{2}{*}{$M(V)$} \\
\hline Private Life & Equality & Civil Liberties & Social Protection & & & \\
\hline No respect & No & No respect & No & 0.04 & 0.2 & 0.1 \\
\hline No respect & No & No respect & Intermediate & 0.26 & 0.53 & 0.33 \\
\hline No respect & No & No respect & Complete & 0.82 & 0.77 & 1.04 \\
\hline No respect & No & Intermediate & No & 0.26 & 0.53 & 0.54 \\
\hline No respect & No & Intermediate & Intermediate & 0.58 & 0.84 & 1.19 \\
\hline No respect & No & Intermediate & Complete & 1 & 0.97 & 1.66 \\
\hline No respect & No & Full respect & No & 1.26 & 1.37 & 1.71 \\
\hline No respect & No & Full respect & Intermediate & 1.78 & 1.69 & 2.51 \\
\hline No respect & No & Full respect & Com & 2.12 & 1.88 & 2.99 \\
\hline No respect & Yes & No respect & No & 1.3 & 1.2 & 1.3 \\
\hline No respect & Yes & No respect & Intermediate & 1.92 & 1.52 & 1.9 \\
\hline No respect & Yes & No respect & Complete & 2.16 & 1.57 & 2.45 \\
\hline No respect & Yes & Intermediate & No & 1.66 & 1.26 & 1.64 \\
\hline No respect & Yes & Intern & Intermedia & 2.2 & 1.44 & 2.38 \\
\hline No respect & Yes & Intermediate & Complete & 3.08 & 1.85 & 3.08 \\
\hline No respect & Yes & Full respect & No & 2.94 & 1.81 & 3.36 \\
\hline No respect & Yes & Full respect & Intermediate & 3.76 & 1.89 & 4.45 \\
\hline No respect & Yes & Full respect & Complete & 4.64 & 2.33 & 5.35 \\
\hline Full respect & No & No re & No & 0.88 & 0.8 & 1.4 \\
\hline Full respect & No & No respect & Intermediate & 1.72 & 1.29 & 2.1 \\
\hline Full respect & No & No respect & Complete & 2.1 & 1.5 & 2.6 \\
\hline Full respect & No & Intermediate & No & 1.46 & 0.95 & 1.61 \\
\hline Full respect & No & Intermediate & Interme & 1.98 & 1.3 & 2.53 \\
\hline Full respect & No & Inter & Com & 3.02 & 1.8 & 3.01 \\
\hline Full respect & No & Full respect & No & 3.24 & 1.66 & 2.9 \\
\hline Full respect & No & Full respect & Intermediate & 3.4 & 1.67 & 3.8 \\
\hline Full respect & No & Full respect & Complete & 4 & 1.94 & 4.43 \\
\hline Full respect & Yes & No respect & No & 3.48 & 1.82 & 2.91 \\
\hline Full respect & Yes & No re & Inte & 4.12 & 2.05 & 3.66 \\
\hline Full respect & Yes & No respect & Complete & 4.64 & 2.27 & 4.28 \\
\hline Full respect & Yes & Intermediate & No & 4.18 & 1.84 & 3.61 \\
\hline Full respect & Yes & Intermediate & Intermediate & 4.84 & 1.89 & 4.78 \\
\hline Full respect & Yes & Intermediate & Complete & 5.92 & 1.95 & 5.55 \\
\hline Full respect & Yes & Full respect & No & 6.76 & 1.81 & 6.35 \\
\hline Full respect & Yes & Full respect & ediate & 7.8 & 1.76 & 7.69 \\
\hline Full respect & Yes & Full respect & Complete & 9.66 & 0.66 & 9.48 \\
\hline
\end{tabular}


French and Venezuelan People's Conceptualization of Human Rights: Indivisibility and...

\section{Appendix B}

\section{Results of the ANOVAs}

\begin{tabular}{|c|c|c|c|c|c|}
\hline & $d f$ & $M S$ & $F$ & $p$ & $\mathrm{Eta}^{2}$ \\
\hline Country (C) & 1 & 27.36 & 0.69 & 0.41 & 0.01 \\
\hline Private Life (P) & 1 & 4953.98 & 551.61 & 0.001 & 0.81 \\
\hline Equality $(\mathrm{E})$ & 1 & 5874.21 & 1116.66 & 0.001 & 0.9 \\
\hline Civil Liberty (L) & 2 & 2418.93 & 865.33 & 0.001 & 0.87 \\
\hline Social Protection (S) & 2 & 748.21 & 374.64 & 0.001 & 0.75 \\
\hline $\mathrm{CxP}$ & 1 & 38.45 & 4.28 & 0.04 & 0.03 \\
\hline $\mathrm{CxE}$ & 1 & 46.52 & 8.84 & 0.004 & 0.06 \\
\hline $\mathrm{CxL}$ & 2 & 6.37 & 2.28 & 0.1 & 0.02 \\
\hline $\mathrm{CxS}$ & 2 & 7.03 & 3.52 & 0.03 & 0.03 \\
\hline $\mathrm{PxE}$ & 1 & 498.38 & 122.59 & 0.001 & 0.49 \\
\hline $\mathrm{PxL}$ & 2 & 106.54 & 46.08 & 0.001 & 0.26 \\
\hline Bilinear & 1 & 195.38 & 60.05 & 0.001 & \\
\hline $\mathrm{E} \times \mathrm{L}$ & 2 & 217.65 & 77.05 & 0.001 & 0.38 \\
\hline Bilinear & 1 & 386.37 & 83.49 & 0.001 & \\
\hline $\mathrm{P} \times \mathrm{S}$ & 2 & 20.32 & 29.64 & 0.001 & 0.19 \\
\hline Bilinear & 1 & 40.46 & 44.05 & 0.001 & \\
\hline $\mathrm{ExS}$ & 2 & 35.27 & 64.56 & 0.001 & 0.34 \\
\hline Bilinear & 1 & 70.16 & 112.02 & 0.001 & \\
\hline $\mathrm{L} \times \mathrm{S}$ & 4 & 14.64 & 27.77 & 0.001 & 0.18 \\
\hline Bilinear & 1 & 57.38 & 74.59 & 0.001 & \\
\hline $\mathrm{CxPxE}$ & 1 & 13.49 & 3.32 & 0.07 & 0.03 \\
\hline $\mathrm{C} \times \mathrm{P} \times \mathrm{L}$ & 2 & 7.93 & 3.43 & 0.03 & 0.03 \\
\hline Trilinear & 1 & 15.66 & 4.81 & 0.03 & \\
\hline $\mathrm{C} \times \mathrm{ExL}$ & 2 & 2.1 & 0.74 & 0.48 & 0.01 \\
\hline $\mathrm{CxP} \times \mathrm{S}$ & 2 & 0.95 & 1.39 & 0.25 & 0.01 \\
\hline $\mathrm{CxExS}$ & 2 & 0.07 & 0.14 & 0.87 & 0 \\
\hline $\mathrm{CxLxS}$ & 4 & 2.53 & 4.8 & 0.001 & 0.04 \\
\hline Trilinear & 1 & 2.17 & 2.82 & 0.1 & \\
\hline$P \times E \times L$ & 2 & 68.85 & 32.85 & 0.001 & 0.2 \\
\hline Trilinear & 1 & 128.08 & 45.2 & 0.001 & \\
\hline $\mathrm{P} \times \mathrm{ExS}$ & 2 & 2.71 & 3.91 & 0.02 & 0.03 \\
\hline Trilinear & 1 & 5.44 & 5.93 & 0.01 & \\
\hline $\mathrm{P} \times \mathrm{L} \times \mathrm{S}$ & 4 & 2.66 & 4.56 & 0.001 & 0.03 \\
\hline Trilinear & 1 & 6.22 & 6.39 & 0.005 & \\
\hline $\mathrm{E} \times \mathrm{L} \times \mathrm{S}$ & 4 & 13.23 & 23.99 & 0.001 & 0.16 \\
\hline Trilinear & 1 & 46.13 & 57.79 & 0.001 & \\
\hline$C \times P \times E \times L$ & 2 & 4.02 & 1.92 & 0.15 & 0.01 \\
\hline $\mathrm{C} \times \mathrm{PxExS}$ & 2 & 0.11 & 0.17 & 0.85 & 0 \\
\hline $\mathrm{C} \times \mathrm{P} \times \mathrm{L} \times \mathrm{S}$ & 4 & 0.36 & 0.61 & 0.65 & 0 \\
\hline $\mathrm{C} \times \mathrm{E} \times \mathrm{L} \times \mathrm{S}$ & 4 & 0.53 & 0.97 & 0.42 & 0.01 \\
\hline$P \times E \times L \times S$ & 4 & 4.47 & 7.84 & 0.001 & 0.06 \\
\hline Quadrilinear & 1 & 10.87 & 14.28 & 0.001 & \\
\hline CxP XExLXS & 4 & 0.77 & 1.35 & 0.25 & 0.01 \\
\hline Quintilinear & 1 & 0.49 & 0.64 & 0.43 & \\
\hline
\end{tabular}

\section{Notes}

* Research article. 